\title{
Pathogenic and enzyme activities of the entomopathogenic fungus Tolypocladium cylindrosporum (Ascomycota: Hypocreales) from Tierra del Fuego, Argentina
}

\author{
Ana C. Scorsetti ${ }^{1 *}$, Lorena A. Elíades ${ }^{1}$, Sebastián A. Stenglein ${ }^{2}$, Marta N. Cabello ${ }^{1,3}$, \\ Sebastián A. Pelizza ${ }^{1,4}$ \& Mario C.N. Saparrat ${ }^{1,5,6}$ \\ 1. Instituto de Botánica Carlos Spegazzini (FCNyM-UNLP) 53 \# 477, (1900), La Plata, Argentina; \\ ascorsetti@conicet.gov.ar, lorenaeliades@yahoo.com \\ 2. Laboratorio de Biología Funcional y Biotecnología (BIOLAB)-CEBB-CONICET, Cátedra de Microbiología, Facultad \\ de Agronomía de Azul, UNCPBA, República de Italia \# 780, Azul (7300), Argentina; stenglein@ faa.unicen.edu.ar \\ 3. Comisión de Investigaciones Científicas de la provincia de Buenos Aires; mcabello@netverk.com.ar \\ 4. Centro de Estudios Parasitológicos y de Vectores (CEPAVE), CCT-La Plata-CONICET-UNLP, Calle 2 \# 584, La Plata \\ (1900), Argentina; pelizza@ cepave.edu.ar \\ 5. Instituto de Fisiología Vegetal (INFIVE), Universidad Nacional de La Plata (UNLP)- CCT-La Plata- Consejo Nacional \\ de Investigaciones Científicas y Técnicas (CONICET), Diag. 113 y 61, CC 327, 1900-La Plata, Argentina; \\ masaparrat@yahoo.com.ar \\ 6. Cátedra de Microbiología Agrícola, Facultad de Ciencias Agrarias y Forestales, UNLP, 60 y 119, 1900-La Plata, \\ Argentina. \\ * Corresponding author
}

\section{Received 27-IV-2011. Corrected 20-VIII-2011. Accepted 14-IX-2011.}

\begin{abstract}
Tolypocladium cylindrosporum is an entomopathogenic fungi that has been studied as a biological control agent against insects of several orders. The fungus has been isolated from the soil as well as from insects of the orders Coleoptera, Lepidoptera, Diptera and Hymenoptera. In this study, we analyzed the ability of a strain of T. cylindrosporum, isolated from soil samples taken in Tierra del Fuego, Argentina, to produce hydrolytic enzymes, and to study the relationship of those activities to the fungus pathogenicity against pest aphids. We have made the traditional and molecular characterization of this strain of $T$. cylindrosporum. The expression of hydrolase activity in the fungal strain was estimated at three incubation temperatures $\left(4^{\circ} \mathrm{C}, 12^{\circ} \mathrm{C}\right.$ and $\left.24^{\circ} \mathrm{C}\right)$, on different agar media supplemented with the following specific substrates: chitin azure, Tween 20 , casein, and urea for chitinase, lipase, protease, and urease activity, respectively. The hydrolytic-enzyme activity was estimated qualitatively according to the presence of a halo of clarification through hydrolase action, besides was expressed semi-quantitatively as the ratio between the hydrolytic-halo and colony diameters. The pathogenicity of the fungus was tested on adults of the aphid Rhopalosiphum padi at three temperatures of incubation $\left(4^{\circ} \mathrm{C}\right.$, $12^{\circ} \mathrm{C}$ and $24^{\circ} \mathrm{C}$ ). The suspension was adjusted to a concentration of $1 \times 10^{7}$ conidia/ml. In pathogenicity assays at seven days post-inoculation, the fungus caused the mortality of adults of Ropalosiphum padi at different temperatures also showed a broad ability to grow on several agar-culture media, supplemented with different carbon sources at the three incubation temperatures tested. Although, the growth was greater with higher incubation temperatures (with maximum levels at $24^{\circ} \mathrm{C}$ ), the fungus reached similar colony diameters after 15 days of incubation on the medium supplemented with Tween ${ }^{\circledR} 20$ at the lower two incubation temperatures of $4^{\circ} \mathrm{C}$ or $12^{\circ} \mathrm{C}$. In accordance with the results on colony diameters, the fungus revealed an ability to degrade casein, chitin derivatives, Tween ${ }^{\circledR} 20$, and urea as evidenced by the appearance of a halo around the fungal colony. Because of its origin and temperature tolerance, this Argentine strain has great potential for use as a biocontrol agent for insect pest control in cold and temperate environments. Rev. Biol. Trop. 60 (2): 833-841. Epub 2012 June 01.
\end{abstract}

Key words: Biological control, chitinolytic activity, entomopathogenesis, hydrolases, soil microorganisms, Tolypocladium cylindrosporum. 
Entomopathogenic fungi are widely distributed over a range of both aquatic and terrestrial habitats, such as the soils of forests, agricultural fields and pastures (Samson et al. 1988, Chandler et al. 1997, Ali-Shtayeh et al. 2002).

Tolypocladium species exist as saprotrophs as well as insect pathogens (Bissett 1983). Tolypocladium cylindrosporum Gams (Ascomycota: Hypocreales) is an entomopathogenic representative of its genus, that has been studied as a biological control agent against insects of several orders (Lam et al. 1988). The fungus has been isolated from the soil as well as from insects of the orders Coleoptera (Elateridae), Lepidoptera (Noctuidae), Diptera (Culicidae, Bibionidae, Anthomyiidae) and Hymenoptera (Sericidae, Formicidae) (Humber \& Hansen 2006). In Argentina, this fungal species was previously isolated from soil in Antarctica and Ushuaia (López Lastra et al. 1991, Martínez et al. 2001).

Different properties of these fungi related to their pathogenicity, virulence factors, and capability to penetrate the insect cuticle have been reported (St Leger 1995). Enzyme complexes such as those catalyzing lipolysis, proteolysis and chitinolysis may be involved in that penetrability. Thus, the level of enzyme activity may also constitute a diagnostic tool for the selection of an efficient biological control agent.

Growth of Beauveria bassiana, Metarhizium anisopliae and Tolypocladium spp. (Ascomycota: Hypocreales) in the haemolymph of the host larvae is associated with the secretion of toxins (secondary metabolites) by the pathogen (Mazet et al. 1994, Clarkson \& Charnley 1996, Bandani et al. 2000). These secondary metabolic peptides of entomogenous fungi, such as destruxins and efrapeptins, are considered to be important virulence determinants (Huxham et al. 1989, Vilcinskas et al. 1997, Bandani et al. 2000).

Early studies by Coudron et al. (1984) demonstrated that chitinolytic activity in several entomopathogens was necessary for growth and potentially needed for penetration. Brandt et al. (1978) proposed that chitinases cause perforations in the external membranes, thus facilitating entry of pathogens into the tissues of susceptible insects.

Information on fungal enzymatic activities involved in insect penetration would be required for the development of an efficient mycotic agent, for insects biological control. Accordingly, in this study, we have analyzed the ability of a strain of $T$. cylindrosporum isolated from soil taken in Tierra del Fuego, Argentina, to produce hydrolytic enzymes and the relationship of those activities to the fungus pathogenicity against pest aphids.

\section{MATERIALS AND METHODS}

Isolation of the fungus: The fungus was isolated from soil samples collected in Ushuaia, in the Tierra del Fuego province, Argentina (544' $\left.48^{\prime \prime} \mathrm{S}-68^{\circ} 21^{\prime} 35^{\prime \prime} \mathrm{W}\right)$, containing a forest system dominated by Nothofagus pumilio (Poepp \& Endl.) Krasser. The soil samples were processed according to the soil-washing method described by Parkinson \& Williams (1961), which technique selects fungal species present as active mycelial forms.

The fungus was taxonomically identified according to Gams (1971) and a specimen deposited at the Instituto de Botánica Carlos Spegazzini (LPSC, La Plata, Buenos Aires, Argentina as LPSC 1065.

Characterization of the strain (LPSC 1065): A monosporic isolate was obtained and inoculated onto a $2 \%(\mathrm{w} / \mathrm{v})$ Malt-extract agar (MEA) with 40000units/ml Penicillin $\mathrm{G}$ (Merck ${ }^{\circledR}$, Germany) and 80000 units $/ \mathrm{mL}$ Streptomycin (Parafarm ${ }^{\circledR}$, Argentina) at $25^{\circ} \mathrm{C}$ in the dark. After $72 \mathrm{~h}$ of incubation, 10 colonyforming units were removed and transferred to sterile Petri dishes containing MEA and incubated for 10 days in the dark at $25^{\circ} \mathrm{C}$. Microscopic and macroscopic descriptions were made from growing cultures according to the standards used by Gams (1971).

For molecular identification genomic DNA was extracted using the CTAB method 
described by Stenglein \& Balatti (2006). PCR was performed to amplify part of the ITS region (ITS3:GCATCGATGAGAACGCAGC/ ITS4:TCCTCCGCTTATTGATATGC). The amplification was carried out in a $50 \mu \mathrm{L}$ final volume containing 12-15ng of genomic DNA, $10 \mathrm{X}$ reaction buffer $(2 \mathrm{mM}$ Tris- $\mathrm{HCl} \mathrm{pH} 8.0$, $10 \mathrm{mM} \mathrm{KCl}, 0.01 \mathrm{mM}$ EDTA, 1mM DTT, 50\% [v/v] Glycerol, 0.5\% [v/v] Tween® 20, 0.5\% [v/v] Nonidet $\left.{ }^{\mathrm{P}} 40\right), 0.5 \mu \mathrm{M}$ of each primer, $200 \mu \mathrm{M}$ of each dNTP (Genbiotech S.R.L.), $2.5 \mathrm{mM} \mathrm{MgCl}_{2}$, and 1.25 units of Taq DNA polymerase (Genbiotech S.R.L.). DNA amplification was performed in an XP thermal cycler (Bioer Technology Co) with an initial denaturing step at $95^{\circ} \mathrm{C}$ for $2 \mathrm{~min}$; followed by 29 cycles at $95^{\circ} \mathrm{C}$ for $30 \mathrm{~s}, 50^{\circ} \mathrm{C}$ for $35 \mathrm{~s}$, and $72^{\circ} \mathrm{C}$ for $45 \mathrm{~s}$; and a final extension cycle at $72^{\circ} \mathrm{C}$ for $2 \mathrm{~min}$. The successful amplification was confirmed by gel electrophoresis. PCR product was purified with the aid of a PureLink PCR purification kit (Invitrogen). DNA sequencing, from both the sense and antisense ends of the fragment was carried out using Big Dye Terminator version 3.1 Cycle Sequencing Ready Reaction Kit (Applied Biosystems, CA) in an Applied Biosystems Sequencer (ABI / Hitachi Genetic Analyzer 3130). Similarities of the fragments with previously published sequence data were examined with BLASTn (Altschul et al. 1990) in the NCBI web page. The sequence generated in this study was submitted to GenBank (accession HQ822271).

Insect rearing: Bird cherry-oat aphids, Rhopalosiphum padi (L.) (Hemiptera: Aphididae) were cultured and assayed on wheat, Triticum aestivum L, in ventilated cages at the insectary of the Instituto Spegazzini, La Plata, Buenos Aires, Argentina, at $24^{\circ} \mathrm{C}$ and $70 \%$ relative humidity with a $16: 8$-h light:dark regime. Aphid-host plants were grown in a steamed-vermiculite:soil:perlite substrate mix of $1: 1: 1$. The pots were placed in a greenhouse at $24 \pm 1^{\circ} \mathrm{C}$, and a photoperiod was provided by incandescent and cool-white lamps, 400nmol m-2 s-1 with 1-week-old wheat plants for bioassays.
Pathogenicity assays: The pathogenicity of the fungus was tested on $R$. padi adults. This pest was chosen, because of their economic importance and cosmopolitan distribution. $T$. cylindrosporum LPSC 1065 was cultured on MEA in Petri dishes and incubated for seven days at $25^{\circ} \mathrm{C}$ in the dark. The conidia were then harvested and placed into test tubes containing $0.01 \%$ (v/v) Tween ${ }^{\circledR} 80$ (sodium polyoxyethylene sorbitan monooleate; Merck $\left.{ }^{\circledR}\right)$. The suspension was adjusted to $1 \times 10^{7}$ conidia/ml after counting in a Neubauer hemocytometer. Experimental insects were sprayed by means of a glass nozzle of 35-cc capacity with $300 \mu \mathrm{L}$ of a conidial suspension, while controls were sprayed with $300 \mu \mathrm{L}$ of $0.01 \%$ (v/v) Tween ${ }^{\circledR}$ 80 alone. The experiment consisted in four replicates and a control group, with 20 insects in each. The insects were then arranged on a wheat leaf placed in a cage (35-mm diameter), with sterilized moistened filter paper at the bottom to maintain a $95 \%$ relative humidity. Both, the treated and the control insects were incubated at different temperatures $\left(24 \pm 1^{\circ} \mathrm{C}\right.$, $12 \pm 1^{\circ} \mathrm{C}$, and $4 \pm 1^{\circ} \mathrm{C}$ ). The cumulative mortality was recorded daily for seven days. Dead insects were removed daily and surface-sterilized by immersion in $70 \%$ (v/v) aqueous ethanol for a few seconds followed by a washing in sterile distilled water, exposure to $0.5 \%$ (w/v) sodium hypochlorite for $1 \mathrm{~min}$, and a final rinsing in distilled water (Lacey \& Brooks 1997). They were next placed in Petri dishes with filter paper moistened with sterile distilled water and were incubated at $25^{\circ} \mathrm{C}$ for 3-5 days to facilitate fungal development. Fungal infections were verified by light microscopy for all the dead insects, which specimens were mounted in lactophenol/cotton blue to confirm infection.

The mortality in the tests was corrected for the mortality recorded in the controls, after Abbot (1925). The median lethal time was estimated according to the methodology cited by Lecuona \& Díaz (2001). The differences in mortality levels among incubations at the differing temperatures were recorded on a weekly basis, the cumulative mortality data evaluated by the analysis of variance 
(ANOVA), and the mean values analyzed by Fisher's least-significant-difference multiplerange-test option $(\mathrm{p}<0.05)$, through the use of the Statgraphics software.

Enzyme activity of the fungal isolate: The expression of hydrolase activity in the fungal strain was estimated on different agar media supplemented with the following specific substrates: chitin azure, Tween ${ }^{\circledR} 20$ (polyoxyethylene sorbitan monolaurate Merck $\left.{ }^{\circledR}\right)$, casein, and urea for chitinase, lipase, protease, and urease activity, respectively.

Chitinase activity was determined according to Howard et al. (2003). For lipolytic activity, an agar medium after Hankin \& Anagnostakis (1975) was used. Casein medium was prepared according to Koneman \& Roberts (1987). Urease activity was estimated on a saline agar $(2 \%, \mathrm{w} / \mathrm{v})$ medium supplemented with $1 \%(\mathrm{w} / \mathrm{v})$ glucose, $2 \%(\mathrm{w} / \mathrm{v})$ urea, and $0.005 \%(\mathrm{w} / \mathrm{v})$ bromocresol purple as a $\mathrm{pH}$ indicator (Ghasemi et al. 2004).

A 6-mm agar plug with mycelium from cultures grown on MEA was inoculated onto the agar surface of every plate and incubated at $4 \pm 1^{\circ} \mathrm{C}, 12 \pm 1^{\circ} \mathrm{C}$ and $24 \pm 1^{\circ} \mathrm{C}$ for 15 days (Saparrat et al. 2008). Three replicates were carried out for each hydrolase incubation and for each temperature, whose results represent the mean values \pm the standard deviation (SD). Fungal growth was estimated by measuring colony diameters. The hydrolytic-enzyme activity was estimated qualitatively according to the

TABLE 1

Cumulative mortality and median lethal time (MLT) caused by T. cylindrosporum LPSC 1065

\begin{tabular}{ccc} 
Treatments & $\begin{array}{c}\text { Cumulative Mortality } \\
( \pm \text { SD })^{*}\end{array}$ & $\begin{array}{c}\text { Median Lethal Time } \\
(\text { MLT 50) }\end{array}$ \\
$4^{\circ} \mathrm{C}$ & $25 \%( \pm 16.39)^{\mathrm{a}}$ & $\mathrm{n} / \mathrm{o}$ \\
$12^{\circ} \mathrm{C}$ & $26.25 \%( \pm 11.81)^{\mathrm{a}}$ & $\mathrm{n} / \mathrm{o}$ \\
$24^{\circ} \mathrm{C}$ & $83.75 \%( \pm 8.53)^{\mathrm{b}}$ & 5.92 days \\
\hline
\end{tabular}

*Data are given in mean $\pm \mathrm{SD}$; values followed by the same letters do not differ significantly according to the LSD test $(\mathrm{p}<0.05) . \mathrm{n} / \mathrm{o}=$ not obtained presence of a halo of clarification through hydrolase action and was expressed semiquantitatively as the ratio between the hydrolytic-halo and colony diameters (Saparrat et al. 2008).

The differences in fungal growth and enzyme activity between treatments were analyzed by the ANOVA and, in turn, the differences between the resulting mean values discriminated by Fisher's least-significantdifference multiple-range-test option $(\mathrm{p}<0.05)$ through the use of the InfoStat software.

\section{RESULTS}

Characterization of $T$. cylindrosporum isolate LPSC 1065: After ten days of incubation on MEA at $25^{\circ} \mathrm{C}$ in the dark, T. cylindrosporum colonies in culture attained a diameter of 19.4 x $20.0 \mathrm{~mm}$ consisting in a symmetrical diameter and regular borders, cottony-flocky surface, white to cream in colour. The reverse of the colony is creamy yellow, smooth, no pigmentation of the medium. Conidiogenous cells phialidic with a swollen base, (3.1) 3.5-

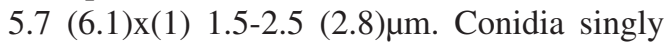
from the tip of the conidiogenous cell, hyaline, smooth, cylindrical of (3) 3.5-4.5 (5.7) $x(1.2) 1.5-1.8(2) \mu m$. The features of this strain agree with the description and illustrations given by Gams 1971.

The amplified product was 344bp in length and the total proportions of nucleotides were $25.58 \%$ A, $29.65 \%$ C, $26.45 \% \mathrm{G}$ and $18.31 \%$ T. BLAST searches of the sequence (GenBank Accession No. HQ822271) showed $100 \%$ of max identity with several sequences of the GenBank (e.g., Accession Nos. AB208110, FJ025179, DQ449656) of T. cylindrosporum (95\% query coverage).

Pathogenicity assays: According to the results obtained from the laboratory pathogenicity assays at seven days post-inoculation, the fungus caused mortality in adults of $R$. padi (Table 1), and fungal growth and sporulation of the isolate became manifest on the dead insects. No mortality occurred in the control insects. At seven days post-inoculation, 
significant differences were observed among the temperatures examined $(\mathrm{F}=25,59 ; \mathrm{df}=2$; 11; $\mathrm{p}=0.0002$ ). At $4^{\circ} \mathrm{C}$ and $12^{\circ} \mathrm{C}$, no median lethal time could be estimated, because the mortality was lower than $50 \%$.

Enzyme activity of the fungus: At the three incubation temperatures tested (Table 2), the fungus showed a broad ability to grow on several agar-based culture media containing different carbon sources which represent, as a model, the components of the insects' chemical constitution.

Although the growth was greater at the higher incubation temperatures (with maximum levels at $24^{\circ} \mathrm{C}$ ), the fungus reached similar colony diameters after 15 days of incubation on the medium supplemented with Tween ${ }^{\circledR} 20$

TABLE 2

Effect of temperature on the growth of T. cylindrosporum LPSC 1065 on different media after 15 days of incubation

\begin{tabular}{lccc} 
Agar-plates & \multicolumn{3}{c}{ Colony diameters $(\mathrm{cm})$} \\
$\quad$ with: & $4^{\circ} \mathrm{C}$ & $12^{\circ} \mathrm{C}$ & $24^{\circ} \mathrm{C}$ \\
Casein & $0.86 \pm 0.05^{\mathrm{a}}$ & $3.2 \pm 0.2^{\mathrm{b}}$ & $4.33 \pm 0.23^{\mathrm{c}}$ \\
Chitin azure & $1.13 \pm 0.11^{\mathrm{a}}$ & $3.66 \pm 0.41^{\mathrm{b}}$ & $5.63 \pm 0.15^{\mathrm{c}}$ \\
Tween 20 & $3.6 \pm 0.36^{\mathrm{a}}$ & $3.6 \pm 0.36^{\mathrm{a}}$ & $4.6 \pm 0.28^{\mathrm{b}}$ \\
Urea & $1.03 \pm 0.15^{\mathrm{a}}$ & $2.75 \pm 0.35^{\mathrm{b}}$ & $3.76 \pm 0.15^{\mathrm{c}}$ \\
\hline
\end{tabular}

*Data are given in mean $\pm \mathrm{SD}$; values followed by the same letters do not differ significantly according to the LSD test across lines $(\mathrm{p}<0.05)$.

TABLE 3

Effect of the temperature on the expression of hydrolase activity of T. cylindrosporum LPSC 1065 on different media after 15 days of incubation

\begin{tabular}{lccc} 
Agar plates & \multicolumn{3}{c}{ Activity halo/growth } \\
\cline { 2 - 4 } with: & $4^{\circ} \mathrm{C}$ & $12^{\circ} \mathrm{C}$ & $24^{\circ} \mathrm{C}$ \\
Casein & $2.12 \pm 0.24^{\mathrm{b}}$ & $1.19 \pm 0.1^{\mathrm{a}}$ & $1.06 \pm 0.08^{\mathrm{a}}$ \\
Chitin azure & $0 \pm 0^{\mathrm{a}}$ & $0.75 \pm 0.21^{\mathrm{b}}$ & $0.73 \pm 0.007^{\mathrm{b}}$ \\
Tween 20 & $0.72 \pm 0.11^{\mathrm{a}}$ & $1.02 \pm 0.03^{\mathrm{b}}$ & $0.94 \pm 0.07^{\mathrm{b}}$ \\
Urea & $1.7 \pm 0.17^{\mathrm{b}}$ & $0.98 \pm 0.02^{\mathrm{a}}$ & $0.62 \pm 0.07^{\mathrm{a}}$ \\
\hline
\end{tabular}

*Data are given in mean $\pm \mathrm{SD}$; values followed by the same letters do not differ significantly according to the LSD test across lines $(\mathrm{p}<0.05)$. at the lower two incubation temperatures of $4^{\circ} \mathrm{C}$ or $12^{\circ} \mathrm{C}$.

In accordance with the results on colony diameters, the fungus revealed an ability to degrade casein, chitin derivatives, Tween ${ }^{\circledR} 20$, and urea as evidenced by the appearance of a halo around the fungal colony. Although, this hydrolytic activity in the fungus was detected in the range of temperatures tested under most conditions, no halo of degradation was seen with chitin azure at $4^{\circ} \mathrm{C}$. In contrast, a bigger halo of degradation with casein and urea was observed at $4^{\circ} \mathrm{C}$, compared to the sizes of the halos at $12^{\circ} \mathrm{C}$ and $24^{\circ} \mathrm{C}$ (Table 3).

\section{DISCUSSION}

In the present investigation we have analyzed the ability of a strain of T. cylindrosporum (LPSC $N^{\circ} 1065$ ) isolated from soil from Tierra del Fuego, Argentina to produce hydrolytic enzymes and the relationship of those activities to the fungus pathogenicity against pest aphids Tolypocladium cylindrosporum has a worldwide distribution and accordingly has been associated with different organic substrates, insect bodies, and the soils of habitats ranging from alpine to temperate to tropical regions.

Temperature is one of the conditions that significantly affect growth and survival, thus determining the efficacy of entomopathogenic fungi as biological control agents (Xavier 1998). Most of those fungi, including several strains of $T$. cylindrosporum, have optimal growth temperatures between $23^{\circ} \mathrm{C}$ and $35^{\circ} \mathrm{C}$ (Roberts \& Campbell 1977, Xavier 1998). Hot and cold temperature conditions are key abiotic environmental influences that may restrict the use of entomopathogenic fungi and molds as agents for the biological control of insects since the host-tolerance limits generally range between $5^{\circ} \mathrm{C}-40^{\circ} \mathrm{C}$ (Pelizza et al. 2007). Because, the area from where the soil was collected has a sub-Antarctic climate (with temperatures ranging between $0{ }^{\circ} \mathrm{C}-9^{\circ} \mathrm{C}$ ), an annual precipitation of about $500 \mathrm{~mm}$, and consequently frequent snow coverage of the soil (Pancotto et al. 2003), and considering that 
temperature is a relevant influence on the production, performance, and efficacy of attack of biocontrol agents, we evaluated the pathogenicity of this fungal isolate against aphids, along with its capacity to produce the appropriate hydrolytic enzymes for the attack process, at $4^{\circ} \mathrm{C}, 12^{\circ} \mathrm{C}$, and $24^{\circ} \mathrm{C}$. T. cylindrosporum was isolated mainly from Diptera, as well as from soil and insects of the orders Coleoptera, Lepidoptera and Hymenoptera (Humber \& Hansen 2006). In this work, we assay pathogenicity on $R$. padi because; it is a cosmopolitan species and has economic importance. Thus, we extend the physiological host range of this entomopathogenic fungus.

Although, bioassays showed that pathogenicity was higher at $24^{\circ} \mathrm{C}$, mortality still occurred at temperatures of $4^{\circ} \mathrm{C}$ and $12^{\circ} \mathrm{C}$. Recently, Pelizza et al. (2007) have reported similar results, suggesting that the differences observed in the fungus's response to temperature are a result of the variability associated with the adaptation to specific habitats. Fungal-strain selection on the basis of thermal requirements may be warranted when choosing a strain for development as an effective microbial control agent for the pests of winter-habitat crops. These considerations suggest that $T$. cylindrosporum LPSC 1065 has a potential for biologically controlling insect that constitute pests at low temperatures.

Loesch et al. (2010) have recently provided information on the capability of a strain of B. brongniartii, BIPESCO 2 (CBS 110631), isolated from $M$. melolontha-infested soil in an alpine area in Austria, to use 120 different carbon compounds at $25^{\circ} \mathrm{C}$. Previous data have been reported on the activity of certain specific enzymes produced by this fungal species in relation to the degradation of the insects' main structural components as well as other organic materials; which hydrolases would constitute putative virulence factors, as specified by several authors for other entomopathogenic fungi (Domsch et al. 1993, St Leger 1995, Xavier 1998, Bandani 2008).

When cultured at $4^{\circ} \mathrm{C}, 12^{\circ} \mathrm{C}$ and $24^{\circ} \mathrm{C}$, our strain LPSC 1065 exhibited extracellular hydrolytic activity on several specific organic model compounds. This result indicates that the fungus has at once proteolytic, lipolytic, chitinolytic and ureolytic activities with the relevant enzymes active at all the temperatures tested. The isolate's ability to use several types of organic substrates at different incubation temperatures might be, at least in part, related to the high nutritional versatility of $T$. cylindrosporum since the fungus has both a parasitic and a saprobic life cycle within its environment (Bandani 2008). The fungus also demonstrates an adaptative response to the variable conditions associated with terrestrial microhabitats where the fungi customarily present are generally confronted with low levels of competition (Zucconi et al. 1996, Tibbett et al. 1999, Pancotto et al. 2003).

Extreme environmental conditions such as high or low temperature may modify and, in particular, inhibit fungal growth, enzyme activity and stability as well as general metabolism, because of the temperature dependence of enzymatic activation and catalysis, protein denaturation, and cell-membrane stability-where disruption of the latter necessarily produces changes in permeability that result in the leakage of cell constituents and/or the prevention of nutrient uptake (Rosset \& Barlocher 1985, Nagai et al. 1995, Pointing et al. 1999, Saparrat et al. 2008). Although, a higher growth was found with increased incubation temperatures in most of the cultures of $T$. cylindrosporum strain LPSC 1065 on the different media used, an effect generally compatible with enzymic kinetic constants and activation energies, this effect was less pronounced with the medium containing Tween ${ }^{\circledR} 20$. This difference no doubt results from the high ability of this fungus to utilize the fatty esters of polyoxyethylene sorbitan, as reported earlier by Loesch et al. (2010) for Tween ${ }^{\circledR} 40$ (polyoxyethylene sorbitan monopalmitate), with both compounds constituting wax-like model substances similar to those present in insect cuticles. With respect to the other hydrolase activities, an opposite response was observed for the protease and urease of the isolate, with 
a higher activities obtaining at lower temperatures; whereas the haloes of chitinolytic and lipolytic activities revealed no differences among the three incubation temperatures tested. Similar to these present observations, the growth at low temperatures of several strains of Hebeloma (Basidiomycota) was found to result in greater proteolytic activity, allegedly because of an activation of those proteases by decreased temperatures (Tibbett et al. 1999). That entomopathogenic fungi in general exhibit many attributes that determine their virulence towards their hosts, including an increased activity of degradation enzymes at low temperatures, suggests that this present isolate is, likewise, a psychrotolerant fungus, as a result of the geographical region where the soil was collected from-i.e., the fungal isolation source. Similarly, Zucconi et al. (1996) categorized Geomyces pannorum var. pannorum (Link) Sigler \& J.W. Carmich strains as psychrotolerant, because of their ability to hydrolyze starch and produce extracellular chitinase, urease and lipase at temperatures below $25^{\circ} \mathrm{C}$.

An understanding of the effects of temperature on the growth and sporulation of entomopathogenic fungi, as well as on the activity and stability of their hydrolases, will assist investigations seeking to use psychrotolerant organisms as biological control agents within the stressful environments generated by low temperatures. Such information is essential for the mass production and commercialization of promising organisms. Additional studies aimed at characterizing the hydrolases activity at low temperatures for cold-resistant entomopathogenic fungi are, however, still needed.

\section{ACKNOWLEDGMENTS}

We thank Verónica Pancotto, for supplying the soil source from Tierra del Fuego, Argentina. This study was partially supported by CICPBA, CONICET (PIP 1422) (PIP 0049) and Facultad de Ciencias Naturales y Museo, Universidad Nacional de La Plata, La Plata, Argentina. Donald Haggerty, a retired career investigator and native English speaker, edited the final version of the manuscript.

\section{RESUMEN}

El hongo entomopatógeno Tolypocladium cylindrosporum ha sido estudiado como un agente de control biológico contra insectos de varios órdenes. Esta especie fue aislada del suelo, así como de insectos de los órdenes Coleoptera, Lepidoptera, Diptera e Hymenoptera. En el presente trabajo hemos analizado la capacidad de una cepa de T. cylindrosporum (LPSC $\mathrm{N}^{\mathrm{o}} 1065$ ) aislada del suelo en Tierra del Fuego, Argentina, para producir enzimas hidrolíticas y determinar la relación de esta actividad con la patogenicidad del hongo para combatir la plaga de los áfidos en diferentes temperaturas $\left(4^{\circ}, 12^{\circ}\right.$ y $\left.24^{\circ} \mathrm{C}\right)$. En los ensayos de patogenicidad, siete días posteriores a la inoculación, se registró mortalidad en los adultos del áfido Ropalosiphum padi a diferentes temperaturas y también se demostró una amplia capacidad de crecer en varios medios de cultivos complementados con diferentes fuentes de carbono bajo las tres temperaturas de incubación ensayadas. Debido a su origen y a la tolerancia que tiene a bajas temperaturas esta cepa, presenta un gran potencial para su uso como agente de control biológico para las plagas de insectos de ambientes fríos y templados.

Palabras claves: control biológico, actividad quitinolítica, entomopatogénesis, hidrolasas, microorganismos de suelo, Tolypocladium cylindrosporum.

\section{REFERENCES}

Abbot, W.S. 1925. A method for computing effectiveness of an insecticide. J. Econ. Entomol. 18: 265-267.

Ali-Shtayeh, M.S., K.H. Tayseer \& R.M. Jamous. 2002. Ecology of dermatophytes and other keratinophilic fungi in swimming pools and polluted and unpolluted streams. Mycopathologia 156: 193-205.

Altschul, S.F., W. Gish, W. Miller, E.W. Myers \& D.J. Lipman. 1990. Basic local alignment search tool. J. Mol. Biol. 215: 403-410.

Bandani, A.R., B.P.S. Khambay, L. Faull, R. Newton, M. Deadman \& T.M. Butt. 2000. Production of efrapeptins by Tolypocladium species (Deuteromycotina: Hyphomycetes) and evaluation of their insecticidal and antimicrobial properties. Mycol. Res. 104: 537-544.

Bandani, A.R. 2008. The effects of entomopathogenic fungus, Tolypocladium cylindrosporum on cellular defence system of Galleria mellonella. J. Agric. Sci. Technol. 10: 135-146. 
Bissett, J. 1983. Notes on Tolypocladium and related genera. Can. J. Bot. 61: 1311-1329.

Brandt, C.R., M.J. Adang \& K.D. Spence. 1978. The peritrophic membrane: ultrastructural analysis and function as a mechanical barrier to microbial infection in Orgyia pseudotsugata. J. Invertebr. Pathol. 32: $12-24$.

Chandler, D., D. Hay \& A.P. Reid. 1997. Sampling and occurrence of entomopathogenic fungi and nematodes in UK soils. Appl. Soil Ecol. 5: 133-144.

Clarkson, J.M. \& A.K. Charnley. 1996. New insight into the mechanisms of fungal pathogenesis in insects. Trends Microbiol. 4: 197-203.

Coudron, T.A., M.J. Kroha \& C.M. Ignoffo. 1984. Levels of chitinolytic activity during development of three entomopathogenic fungi. Comp. Biochem. Phys. B. 79: $339-348$.

Domsch, K.H., W. Gams \& T. Anderson. 1993. Compendium of soil fungi. Verlag, Germany.

Gams, W. 1971. Tolypocladium, eine Hyphomycetengattung mit geschwollenen Phialiden. Persoonia 6: 185-191.

Ghasemi, M.F., M.R. Bakhtiari, M. Fallahpour, A. Noohi, N. Moazami \& Z. Amidi. 2004. Screening of urease production by Aspergillus niger strains. Iran. Biomed. J. 8: 47-50.

Hankin, L. \& S.L. Anagnostakis. 1975. The use of solid media for detection of enzyme production by fungi. Mycologia 67: 597-607.

Howard, M.B., N.A. Ekborg, R.M. Weiner \& S.W. Hutcheson. 2003. Detection and characterization of chitinases and other chitin-modifying enzymes. J. Ind. Microbiol. Biot. 30: 627-635.

Humber, R.A. \& K.S. Hansen. 2006. ARSEF, USDA-ARS Collection of Entomopathogenic Fungal Culture. (also available online: http://arsef.fpsnl.cornell.edu).

Huxham, I.M., A.M. Lackie \& N.J. McCorkindale. 1989. Inhibitory effects of cyclodepsipeptides, destruxins, from the fungus Metarhizium anisopliae, on cellular immunity in insects. J. Insect Physiol. 35: 97-105.

Koneman, E. \& G. Roberts. 1987. Micología. Práctica de laboratorio. Editorial Médica Panamericana S.A., Buenos Aires, Argentina.

Lacey, L. \& W.M. Brooks. 1997. Initial handling and diagnosis of diseased insects, p. 1-12. In L. Lacey (ed.).
Manual of techniques in insect pathology. Academic, San Diego, California.

Lam, T.N.C., M. Goettel \& G.G. Jr Soares. 1988. Host Records for the entomopathogenic Hyphomycete Tolypocladium cylindrosporum. Fla. Entomol. 71: 86-89.

Lecuona, R.E. \& B.M. Díaz. 2001. Susceptibilidad de Spodoptera frugiperda (J.E. Smith) a los hongos entomopatógenos Nomuraea rileyi, Metarhizium anisopliae y Beauveria bassiana. Rev. Invest. Agropecu. 30: $25-42$.

Loesch, A., S. Hutwimmer \& H. Strasser. 2010. Carbon utilization pattern as a potential quality control criterion for virulence of Beauveria brongniartii. J. Invertebr. Pathol. 104: 58-65.

López Lastra, C.C., G.R. Reboredo \& H. Spinedi. 1991. Primer registro de Tolypocladium cylindrosporum Gams (Deuteromycotina:Hyphomycetes) para la Antártida. Consideraciones sobre su patogenicidad sobre larvas de Culex pipiens L. Contrib. Inst. Antart. 392: 11 .

Martínez, A.E., V.M. Chiocchio \& A.M. Godeas. 2001. Hyphomycetes celulolíticos en suelos de bosques de Nothofagus, Tierra del Fuego. Gayana Bot. 58: 123-132.

Nagai, K., T. Sakai, R.M. Ratiatmodjo, K. Suzuki, W. Gams \& G. Okada. 1995. Studies on the distribution of alkalofphilic and alkali- tolerant soil fungi I. Mycoscience 36: 247-256.

Mazet, I., S.Y. Hung \& D.G. Boucias. 1994. Detection of toxic metabolites in the hemolymph of Beauveria bassiana infected Spodoptera exigua larvae. Cell. Moll. Life Sci. 50: 142-147.

Pancotto, V.A., O.E. Sala \& M. Cabello. 2003. Solar UV-B decreases decomposition in herbaceous plant litter in Tierra del Fuego, Argentina: Potential role of an altered decomposer community. Glob. Change Biol. 9: 1465-1474.

Parkinson, D. \& S.T. Williams. 1961. A method for isolating fungi from soil microhabitats. Plant Soil 13: 347-355.

Pelizza, S.A., C.C. López Lastra, J.J. Becnel, V. Bisaro \& J.J. Garcia. 2007. Effect of temperature, $\mathrm{pH}$, and salinity on the infection of Leptolegnia chapmanii Seymour (Peronosporomycetes) in mosquito larvae. J. Invertebr. Pathol. 96: 133-137.

Pointing, S.B., J.A. Buswell, E.B. Gareth Jones \& L.L.P. Vrijmoed. 1999. Extracellular cellulolytic enzyme 
profiles of five lignicolous mangrove fungi. Mycol. Res. 103: 696-700.

Roberts, D.W. \& A.S. Campbell. 1977. Stability of entomopathogenic fungi. Misc. Publ. Entomol. Soc. Am. 10: $19-76$.

Rosset, J. \& F. Barlocher. 1985. Aquatic Hyphomycetes: influence of $\mathrm{pH}, \mathrm{Ca}^{2+}$ and $\mathrm{HCO}_{3}^{-}$on growth in vitro. T. Brit. Mycol. Soc. 84: 137-145.

Samson, R.A., H.C. Evans \& P. Latge. 1988. Atlas of entomopathogenic fungi. Springer-Verlag, Berlin, Germany.

Saparrat, M.C.N., M. Rocca, M.B. Aulicino, A. Arambarri \& P. Balatti. 2008. Celtis tala and Scutia buxifolia leaf litter decomposition by selected fungi in relation to their physical and chemical properties and the lignocellulolytic enzyme activity. Eur. J. Soil Biol. 44: 400-407.

St Leger, R.J. 1995. The role of cuticle-degrading proteases in fungal pathogenesis of insects. Can. J. Bot. 73: 1119-1125.
Stenglein, S.A. \& P.A. Balatti. 2006. Genetic diversity of Phaeoisariopsis griseola in Argentina as revealed by virulence and molecular markers. Physiol. Mol. Plant P. 68: 158-167.

Tibbett, M., F.E. Sanders, J.W.G. Cairney \& J.R. Leake. 1999. Temperature regulation of extracellular proteases in ectomycorrhizal fungi (Hebeloma spp.) grown in axenic culture. Mycol. Res. 103: 707-714.

Vilcinskas, A., V. Matha \& P. Gotz. 1997. Inhibition of phagocytic activity of plasmatocyes isolated from Galleria mellonella by entomogenus fungi and their secondary metabolites. J. Insect Physiol. 43: 475-483.

Xavier, I.J. 1998. Environmental stress response of the Hyphomycetous Entomopathogenic fungi. Ph.D. Thesis, University of Saskatchewan, Saskatoon, Canada.

Zucconi, L., S. Pagano, M. Fenice, L. Selbmann, S. Tosi \& S. Onofri. 1996. Growth temperature preferences of fungal strains from Victoria Land, Antarctica. Polar Biol. 16: 53-61. 
